\title{
Primary Elections and Partisan Polarization in the U.S. Congress
}

\section{Citation}

Hirano, Shigeo, James M. Snyder Jr., Stephen Daniel Ansolabehere, and John Mark Hansen. 2010. Primary elections and partisan polarization in the U.S. Congress. Quarterly Journal of Political Science 5(2): 169-191.

\section{Published Version}

doi:10.1561/100.00008052

\section{Permanent link}

http://nrs.harvard.edu/urn-3:HUL.InstRepos:9949294

\section{Terms of Use}

This article was downloaded from Harvard University's DASH repository, and is made available under the terms and conditions applicable to Other Posted Material, as set forth at http:// nrs.harvard.edu/urn-3:HUL.InstRepos:dash.current.terms-of-use\#LAA

\section{Share Your Story}

The Harvard community has made this article openly available.

Please share how this access benefits you. Submit a story.

Accessibility 


\title{
Primary Elections and Partisan Polarization in the U.S. Congress*
}

\author{
Shigeo Hirano ${ }^{1}$, James M. Snyder, Jr. $^{2}$, Stephen Ansolabehere ${ }^{3}$ and \\ John Mark Hansen ${ }^{4}$ \\ ${ }^{1}$ Department of Political Science, Columbia University, USA, sh145@columbia.edu \\ ${ }^{2}$ Departments of Political Science and Economics, Massachusetts Institute of Technology and \\ NBER,USA,millett@mit.edu \\ ${ }^{3}$ Department of Government, Harvard University, USA, sda@gov.harvard.edu \\ ${ }^{4}$ Department of Political Science, University of Chicago, USA, \\ jhansen@midway.uchicago.edu
}

\begin{abstract}
Many observers and scholars argue that primary elections contribute to ideological polarization in U.S. politics. We test this claim using congressional elections and roll call voting behavior. Many of our findings are null. We find little evidence that the introduction of primary elections, the level of primary election turnout, or the threat of primary competition are associated with partisan polarization in congressional roll call voting. We also find little evidence that extreme roll call voting records are positively associated with primary election outcomes. A positive finding is that general election competition exerts pressure toward convergence as extreme roll call voting is negatively correlated with general election outcomes.
\end{abstract}

* This paper is part of a project supported by National Science Foundation Grant Number SES0617556. The opinions, findings, and conclusions or recommendations expressed in this article do not necessarily reflect the views of the National Science Foundation. We thank participants at the 2008 Midwest Political Science Association Conference and David Mayhew for their helpful comments and suggestions. Shigeo Hirano thanks the Center for the Study of American Politics at Yale University for institutional and financial support.

Supplementary Material available from: http://dx.doi.org/10.1561/100.00008052_supp

MS submitted 15 Fuly 2008; final version received 24 March 2010

ISSN 1554-0626; DOI 10.1561/100.00008052

(C) 2010 S. Hirano, J. M. Snyder Jr., S. Ansolabehere and J. M. Hansen 


\section{INTRODUCTION}

Direct primary elections are widely believed to having a polarizing effect on the U.S. Congress. ${ }^{1}$ The need to win primary elections in order to secure a seat in Congress potentially creates a motivation for congressional candidates to take extreme policy positions to satisfy their party electorates. Jacobson $(2004$, p. 16) writes, "Primary electorates are much more partisan and prone to ideological extremity, and the need to please them is one force behind party polarization in Congress." ${ }^{2}$ The polarizing effect of primary elections has gained renewed interest in recent years as a potential explanation for the rise in partisan polarization in the U.S. Congress over the last three decades.

This view that primaries have a polarizing effect on the policy positions of members of Congress (MCs) is also frequently expressed in the media. Here is one example from the Chicago Tribune: "Voters in primaries are generally political activists who represent the ideological extremes of the two major parties. Thus, Democrats tend to choose candidates who are more liberal than the general electorate and Republicans tend to choose candidates who are more conservative than the general electorate" (Markus, 1992, p. 20). MCs, knowing they will need to satisfy their primary electorates, have an incentive to continue to take extreme roll call voting positions once in Congress.

Political economy models with candidates competing in primary and general elections formalize the logic for how primary competition leads to polarization (e.g., Aranson and Ordeshook, 1972; Coleman, 1972; Owen and Grofman, 2006). These models predict that when an ideological divide exists between the primary electorates of the two parties and primary elections are fully contested, strategic candidates will take policy positions away from the general election median voter and toward the median voter of their primary electorate.

Although the conventional wisdom suggests that the introduction of primary elections will have a polarizing effect on the positions of members of Congress, there are surprisingly few empirical studies that test this idea directly. Thus, the first question we ask in this paper is: Do members of Congress take more extreme policy positions after the introduction of mandatory direct primary laws in their state? To identify whether such a relationship exists, we exploit variation in the timing of states' adoption of mandatory direct primary laws. We find no evidence that the introduction of primaries is associated with MCs taking more extreme roll call voting positions.

1 See Brady et al. (2007), Burden (2001, 2004), Fiorina et al. (2006), Fiorina and Levendusky (2006), Hacker and Pierson (2006), Jacobson (2004), King (2003), Sinclair (2006), and Wright and Berkman (1986).

2 Carey and Polga-Hecimovich (2006, p. 530) write, "Primaries attract hardcore partisans, who tend to come from the ideological extremes of the two big parties, and these voters in turn choose candidates of limited appeal to the middle-of-the-road voters who dominate the general electorate." Sinclair (2006, pp. 29-30) writes that activists "always vote, they vote in primaries, and they give money or work for candidates. To win in the primary, the candidate needs to be especially attentive and responsive to activists who are more polarized than less interested voters. The candidates who emerge from primaries are likely to be acceptable to the activist." 
In the second part of this paper we examine whether certain conditions strengthen the polarizing effect primaries have on roll call voting behavior. The literature highlights two variables that are believed to affect the relationship between primaries and polarization: (i) the degree to which the primary electorates are polarized; and (ii) the degree to which MCs face electoral threats from primary challengers.

A common argument in the literature is that the rising polarization in Congress is due to the increasing ideological extremism of the primary electorate. This change in the primary electorate is often attributed to greater ideological sorting among partisans (Fiorina et al., 2006; Fiorina and Levendusky, 2006) and/or to declining turnout among primary voters (King, 2003). However, there is little direct empirical evidence to connect the increasing ideological extremism of primary electorates to polarization in Congress. ${ }^{3}$ We exploit the variation in turnout between states and overtime to ask a simple question: Is the level of primary election turnout associated with roll call voting positions of members of Congress? We find little evidence that low primary turnout is associated with the selection of senators with extreme roll call voting positions or with changes in incumbent senators' roll call voting positions over time.

Another common argument is that the rising polarization in Congress is due to the increasing threat MCs face from potential primary election challengers. In particular, partisan gerrymandering is argued to have led House members to be more concerned with primary rather than general election challengers. McCarty et al. (2006, p. 666) summarize the argument as follows: "Presumably in an era of declining competition politicians no longer feel the need to reach out to moderate and independent voters to win elections. Instead politicians are free to pander to their ideological and partisan base. Politicians who do not pander may face primary challenges by ideologically purer candidates."4 Several empirical studies examine the relationship between primary competition MCs

3 A notable exception is the study by Gerber and Morton (1998). They exploit the connection between primary laws and the ideological and partisan composition of voters eligible to vote in primaries to show that members of Congress nominated in "closed" primaries tend to have policy positions that are farther from the preferences of their general electorate than those nominated in more "open" primaries. However, the effect they find is rather modest and does not rule out the possibility that the results may be reflecting other state characteristics correlated with primary election laws. Bullock and Clinton (2010) also find only modest effects when they investigate the move to blanket primaries in California.

4 Hetherington (2009, p. 423) describes the redistricting and polarization argument as follows: "The absence of inter-party competition in most elections is potentially important because a vast majority of members need not worry much about losing elections if they are more ideologically extreme than their district. Such a member would, on average, face more peril in a primary election. Importantly, primary election constituencies, especially those in closed primary states, ought to be more ideologically extreme than general election constituencies." Mann $(2005$, p. 4) writes, "Many observers and participants believe redistricting fuels this polarization, by creating safe seats in which incumbents have strong incentives to reflect the views of their party's most extreme supporters - i.e., those active in primary elections - and little reason to reach out to swing voters." Galston and Nivola (2006, p. 25) write, "The direct primary (or threat thereof), not the general election, becomes the defining political event." 
face and polarization in their roll call voting behavior. These studies provide mixed results. 5

Our analysis differs from existing studies on primary competition and polarization by using a measure of the potential threat of primary competition rather than the actual competition MCs face in their previous election. Since strategic candidates are likely to adjust their position to minimize electoral threats, whether MCs face primary competition is unlikely to be an accurate measure of the actual underlying primary threat they face. ${ }^{6}$ Hacker and Pierson $(2006$, p. 126) write that "even when a primary challenge does not materialize, the fact that one might occur can effectively pull candidates toward their base." We present a simple model to demonstrate how using MCs' own observed primary competition to measure the threat of primary competition can produce biased estimates of the relationship between primary competition and roll call voting behavior. The model isolates two sources of bias - endogeneity and measurement error. We then discuss how using a variable based on primary election returns for down-ballot statewide offices to measure the threat of primary competition will, in some cases, be less susceptible to the same endogeneity and measurement error concerns. Using this alternative measure we ask: Is the variation in the threat of potential primary competition across states related to senators' roll call voting behaviors? We find little evidence that such a relationship exists.

Overall, the various empirical investigations suggest that primary elections do not have a large impact on MCs' roll call voting positions, even when the ideological composition of the primary electorate appears to be relatively extreme or when the threat of primary competition appears to be particularly strong.

In the final section of this paper, we briefly investigate why the conventional wisdom may not reflect the actual relationship between primaries and polarization in Congress. In particular we examine whether primary elections provide the strong electoral incentive for candidates to take extreme positions as suggested by the conventional wisdom. Brady et al. (2007) find evidence that House members with more extreme roll call voting positions have relatively higher primary election vote shares. Our analysis exploits the multi-member district feature of Senate elections to examine whether differences in roll call voting positions of senators from the same party and same state are related to differences in the senators' primary vote shares. We find no evidence that a significant association exists between senators' roll call voting positions and their primary election returns. However, we do find a significant negative correlation between extreme roll call voting positions and general election returns. This suggests that the logic underlying the conventional wisdom may not accurately reflect the degree to which primaries provide an electoral motivation for candidates to take extreme policy positions.

See Ansolabehere et al. (2001), Burden (2004), and Pearson and Lawless (2007).

6 Fiorina and Levendusky (2006, p. 70) write, "Even though few incumbents face serious primary challenges, it would be a mistake to conclude that primary elections are unimportant. In all likelihood, incumbents act strategically to preclude primary challenges. Even if they are unlikely to face a challenge, candidates take special pains to maintain the support of their party's hard-core voters." 


\section{POLARIZATION AND THE INTRODUCTION OF PRIMARIES}

In this section we ask a simple question: Do members of Congress take more extreme policy positions following the introduction of mandatory direct primary elections in their state? We exploit variation in the adoption of state laws making primary elections mandatory to test whether MCs changed their roll call voting positions once they began being nominated through primary elections. In particular we examine seven states which introduced direct primary laws for congressional elections after the New Deal realignment: Connecticut (1956), Delaware (1970), Indiana (1976), New Mexico (1940), New York (1968), Rhode Island (1948), and Utah (1938). ${ }^{7}$ We focus on this later period since the issues separating the Democratic and Republican parties probably differed significantly before and after the New Deal. ${ }^{8}$

Although not a random sample, these states provide us at least some insight into whether the introduction of mandatory primaries have a general polarizing effect on the roll call voting behavior of MCs. According to the logic discussed above, MCs should adjust their policy positions to account for the electoral insecurity they potentially face if the primary voters choose to back a candidate with more extreme policy positions.

Before proceeding, we must state how polarization is defined in this paper. We focus on the contribution of individual MCs to polarization. For Republicans we define individual $i$ 's contribution to polarization in Congress $t, I_{i t}$, as $\left(N_{i t}-\bar{N}_{R t}\right)$ where $N_{i t}$ is MC $i$ 's DW-NOMINATE score in Congress $t$ and $\bar{N}_{R t}$ is the average nominate score for all Republicans in Congress $t$. For Democrats, $I_{i t}$ is $-\left(N_{i t}-\bar{N}_{D t}\right)$, where $\bar{N}_{D t}$ is the average nominate score for all Democrats in Congress $t$. Note that we orient the roll call scores so that higher values of $I_{i t}$ are associated with larger contributions to polarization. In addition, we measure individuals relative to their parties. We do this in order to account for factors that affect all members within a party. This helps us isolate the effect of primaries, by taking advantage of variation in the primary election environment across states within years.

Consider the seven states identified above that adopted mandatory primary elections after the New Deal. Figure 1 plots the average of the $I_{i t}$ 's for each Congress for the four Congresses before and after these states introduced mandatory direct primary elections. Evidently there was no sharp change in the average relative positions of MCs in these states after the introduction of primaries. If MCs were anticipating the move to direct primaries then we might expect the change in policy positions to occur before the

7 Indiana and New York introduced primary elections for the House earlier, so they are dropped from our analysis of House members' positions.

8 Although we do not have survey data about the ideological positions of Democratic and Republican voters prior to 1964, we do have Gallup Poll responses for the early post-New Deal period on questions related to the current ideological division between Democrats and Republicans. This poll data shows, for example, identification with the Democratic (Republican) party is positively (negatively) correlated with whether a respondent believed that the government should guarantee jobs. 


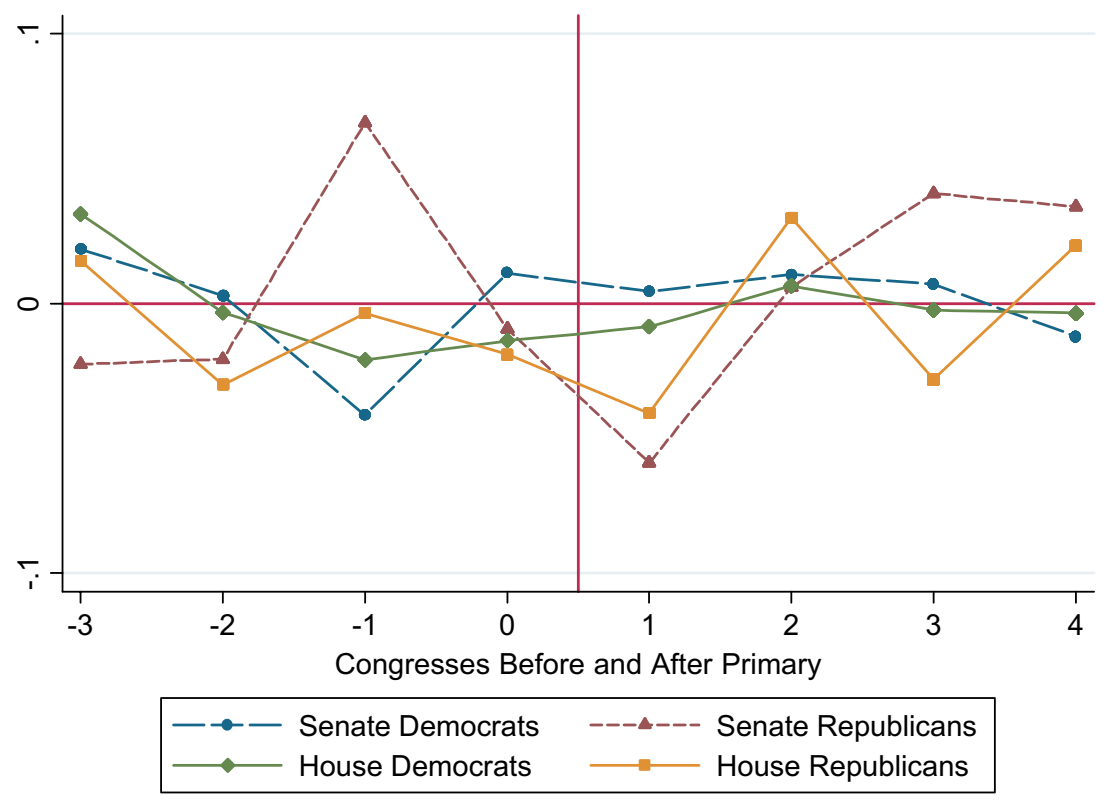

Figure 1. Introduction of direct primaries and individual contribution to polarization.

introduction of primaries. We do not observe a significant increase in the polarization of roll call voting positions even if we compare the position of MCs a few years before or after the introduction of mandatory primaries.

We use the following specification to further examine whether there was a significant change in the roll call voting positions of MCs after the introduction of mandatory primary laws in the above mentioned states:

$$
I_{i j k t}=\alpha_{j k}+\theta M_{j k t}+\gamma_{k t}+\epsilon_{i j k t},
$$

where $I_{i j k t}$ is as defined above for member of Congress $i$ in state $j$ and party $k$ for Congress $t ; M_{j k t}$ is an indicator for whether state $j$ 's party $k$ mandated that its congressional candidates be nominated through direct primaries in the election to Congress $t$; and $\alpha_{j k}$ and $\gamma_{k t}$ are state-party and Congress-party fixed effects, respectively. We focus on the period 1932-2006.

The results, shown in Table 1, provide no systematic evidence that MCs in the late primary adoption states began taking more extreme roll call voting positions following the introduction of mandatory primary election laws in their state. If anything, the estimates of $\theta$ suggest that MCs in these states took more moderate positions after primaries were introduced in their states. Thus, mandatory primaries do not appear to have had any more of a polarizing effect on roll call voting behavior compared to the previous nominating procedures used in these states. 
Table 1. Introducing direct primary elections and polarization in Congress, 1932-2006.

\begin{tabular}{lccc}
\hline & All & Democrats & Republicans \\
\hline Senate & & & \\
Direct Primary & -0.043 & -0.008 & -0.094 \\
& $(0.035)$ & $(0.036)$ & $(0.065)$ \\
Observations & 3,800 & 2,158 & 1,642 \\
House & & & \\
Direct Primary & -0.078 & -0.051 & -0.115 \\
& $(0.025)$ & $(0.027)$ & $(0.025)$ \\
Observations & 16,645 & 9,624 & 7,021 \\
\hline
\end{tabular}

The above table provides the estimates of $\hat{\theta}$ from Equation (1). Stateparty and Congress fixed effects are included in all of the models but are not shown. Standard errors clustered by state-party are in parentheses.

\section{POLARIZATION AND IDEOLOGICAL COMPOSITION OF PRIMARY VOTERS}

In this section we investigate whether the ideological composition of the primary electorate affects the relationship between primaries and roll call voting behavior. Since the extreme preferences of the primary electorate are believed to pull MCs away from the median voter of the general electorate, we would expect that more extreme primary electorates are associated with more extreme policy positions by MCs.

Various scholars have noted that the ideological gap between the primary electorates has been increasing at the same time as political parties have become more polarized in Congress (Fiorina et al., 2006; Fiorina and Levendusky, 2006). The changing ideological composition of the primary electorates is commonly attributed to either an increase in sorting among partisans - conservatives (liberals) are less likely to be Democrat (Republican) than in the past - and/or to declining primary election turnout that is associated with lower participation of ideological moderates (King, 2003). ${ }^{9}$ However, there is little systematic evidence linking the changes in the composition of the primary electorate and polarization in Congress.

In our empirical analysis we focus on whether the changes in composition of the primary electorate associated with changes in turnout levels are systematically related

9 Fiorina and Levendusky (2003, p. 71) summarize the sorting argument as follows: "Because sorting produces a more homogeneous and a more extreme primary electorate, the pressure increases for candidates to take consistently liberal or conservative positions on most issues, even when moderation would be more helpful in the general election. Thus sorted partisans move candidates toward noncentrist positions." 
to the variation in MCs' roll call voting positions. Both scholars and journalists claim that as primary turnout declines the primary electorate becomes more partisan and ideologically extreme. Fiorina and Levendusky (2006, p. 70) write, "As noted previously, turnout in primary elections is usually very low, so a few core committed supporters (at least on the lower rungs of the electoral ladder) can be a critically important foundation for a campaign." An op-ed in the Washington Post states the following: "Falling turnout in primary elections, particularly in congressional races in off years, cedes the field to fiery partisans." ${ }^{10}$ Unlike the "sorting" argument, the changes in the preferences of the primary electorate due to variation in primary election turnout are not necessarily correlated with the changes in the preferences of the general electorate. If turnout affects the preferences of the primary electorate without significantly affecting the preferences of the general electorate, then this will allow us to identify the effect of primary electorate composition separate from the effect of general electorate composition. ${ }^{11}$ Thus, according to the conventional wisdom we should expect low turnout to be associated with extreme roll call voting positions by MCs.

Although we focus on the variation in ideological composition of the primary electorate associated with variation in turnout, we also measure the ideological composition of state primary electorates more directly using presidential primary exit poll data. According to the conventional wisdom, we should expect that the states where the primary exit poll respondents take more extreme ideological positions to also be the states represented by senators with more extreme roll call voting positions.

\section{Turnout and Congressional Polarization}

Primary election turnout for statewide offices has declined during the period when Congress has become more polarized. Figure 2 plots primary election turnout for statewide offices as a proportion of total voting age population averaged by decade. We use the highest turnout among the offices as a measure of turnout for that election year. ${ }^{12}$ The figure illustrates the decline in average level of turnout for state primaries between the 1970 s and 2000s.

Before examining the relationship between turnout and roll call voting behavior, we first use presidential primary and general election exit poll data to verify that primary

10 Op-Ed. "A Polarized Nation?" The Washington Post November 14, 2004. Also Ornstein (2006) writes in the Nem York Times, "The unhappy effects of low turnout are clear: ever-greater polarization in the country and in Washington, which in turn has led to ever-more rancor and ever-less legislative progress."

11 The existing empirical evidence that primary election voters are more extreme than general election voters is mixed. Whether one observes a difference in the ideological positions of these two electorates depends in part upon the states and the elections investigated (e.g., Key, 1956; Ranney and Epstein, 1966; Ranney, 1968; Lengle, 1981; Crotty and Jackson, 1985; Norrander, 1989; Abramowitz, 2008). If candidates take positions to appeal to their base in the general election (e.g., Huntington, 1950; Fiorina, 1974), then we could observe polarization in Congress due to sorting even when primaries do not affect roll call voting behavior.

12 See Ansolabehere et al. (2006b) for the sources of the primary returns data. The voting age population data is from the U.S. Bureau of Economic Analysis. 


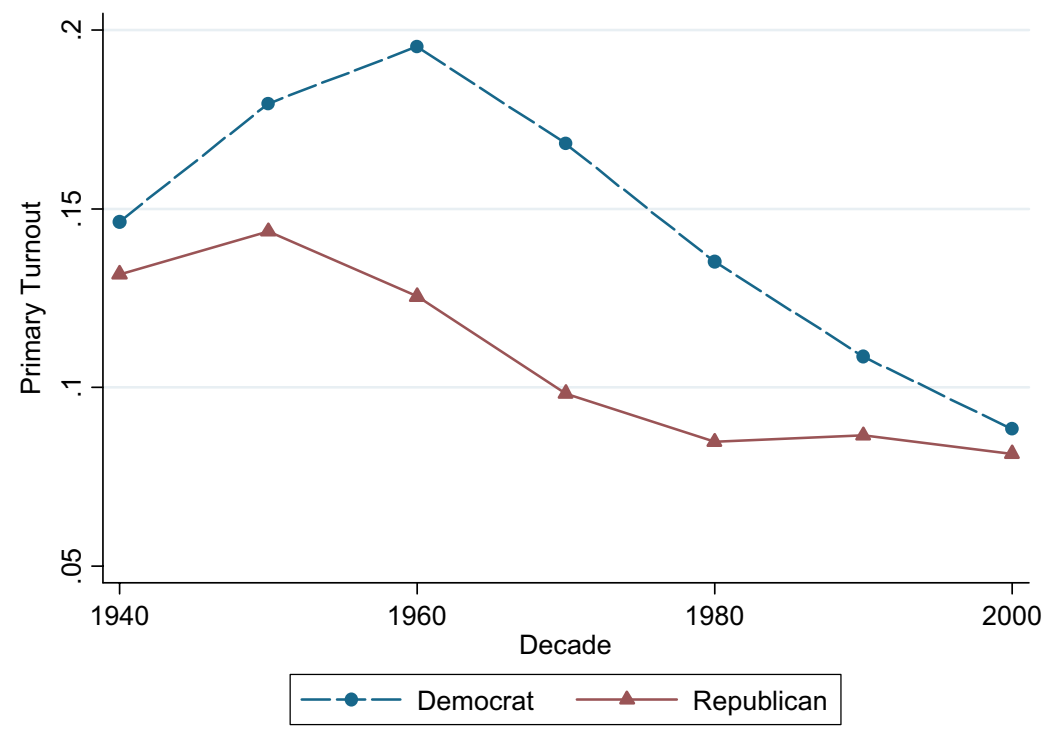

Figure 2. Statewide primary election turnout over time.

election turnout is related to the ideological position of the primary electorates. ${ }^{13}$ In these polls respondents were asked their ideological position on a three-point scale. For each presidential election we can calculate the average ideological position of the primary election exit poll respondents from each state. ${ }^{14}$ We then average these measures for the four presidential elections between 1992 and 2004.

A simple regression of the primary electorates' ideological extremism on the primary election turnout and the general electorates' ideological extremism provides evidence that primary election turnout is negatively correlated with the primary electorate's ideological position. ${ }^{15}$ Unfortunately, we do not have primary election exit poll surveys for statewide office elections, so we assume that a similar pattern exists between turnout

13 Not all states had exit poll surveys. We have both Democratic and Republican party exit poll surveys for AL, AZ, CA, CO, CT, DE, FL, GA, IL, IN, KS, LA, MA, MD, ME, MN, MO, MS, NC, NH, NJ, NY, OH, OK, OR, PA, RI, SC, SD, TN, TX, VA, VT and WI. In addition we have Republican exit poll surveys for MI, ND, UT, and WA.

14 As with roll call positions we adjust the ideological positions so that higher scores indicate more extreme positions for both parties.

15 We use the following specification: $\bar{P}_{j k}=\alpha_{k}+\theta_{1 k} \bar{G}_{i k}+\theta_{2 k} \bar{T}_{j k}+\epsilon_{j k}$, where $\bar{P}_{j k}$ is the average ideological position of the respondents who voted in the party $k$ 's presidential primary in state $j$; $\bar{G}_{j k}$ is the average ideological position of respondents who identified with party $k$ in the presidential general election in state $j$; and $T$ is a measure of primary election turnout. We measure primary election turnout as the votes cast as a proportion of the voting age population. We use the average of these variables across the four elections between 1992 and 2004. We find substantively similar results if we do not average across the four elections but treat each election as a separate observation. The results can be found in Table A1. 
and electoral polarization in primary elections for statewide offices. These results suggest that if the ideological composition of the primary electorate affects roll call voting behavior then we should expect senators to have more extreme (moderate) roll call voting positions when primary turnout is low (high).

To estimate the relationship between senators' roll call voting positions and primary turnout we use the following specification:

$$
I_{i j k t}=\alpha_{j k}+\theta T_{j k t}+\gamma_{k t}+\epsilon_{i j k t},
$$

where $I_{i j k t}$ is the individual contribution to polarization of senator $i$ who is first elected in state $j$ for party $k$ in year $t$; and $T_{j k t}$ is the maximum turnout among the statewide office primaries in state $j$ 's party $k$ in year $t$. We measure primary election turnout as the votes cast as a proportion of the voting age population. ${ }^{16} \alpha_{j k}$ is state-party fixed effect, which we allow to vary for the periods before and after 1974 to account for the fact that preferences within states may have shifted over time. $\gamma_{k t}$ is a Congress-party fixed effect. Our analysis covers the half-century between 1948 and 2006. The standard errors are clustered by state-party.

First we focus on newly elected senators, since changes in roll call voting patterns are often believed to occur through replacement rather than through adaptation (Stone, 1980; Poole, 1997). Theriault (2006) claims that congressional polarization is due mainly to replacements. Thus we might suspect that senators who are first elected in a year with low primary turnout will take extreme policy positions that reflect the preferences of their primary electorate.

The estimates of $\theta$ for newly elected senators are in columns 1 and 2 of row 1 of Table 2. Since we have relatively few observations of newly elected senators for a given party in each year, we do not include Congress-party fixed effects. The estimate in column 1 is negative but not statistically significant. Although the sign on this coefficient is consistent with the claims that ideologically extreme primary electorates nominate more extreme candidates, the magnitude of the average effect is small. A two-standarddeviation increase in turnout is associated with a shift in the individual contribution to polarization of less than 0.08 of a standard deviation. Note that while the standard errors are also large, even if we use the largest estimate of $\theta$ within the $95 \%$ confidence interval, a two-standard-deviation increase in turnout is associated with a decrease in the individual contribution to polarization of less than 0.40 of a standard deviation. Furthermore, when state-party fixed effects are included (column 2), the estimate of $\theta$ is positive, the opposite of what we would expect given the popular claims.

Next, we examine whether there is any evidence that senators in general were responding to long-term trends in turnout within their states. We use the same specification

16 We had hoped to also exploit the variation in primary election turnout that occurs due to whether the congressional primary is on the same day as a presidential primary. We find that congressional primary turnout is only affected when the presidential primary is on the same day and is also contested. There are very few cases in our data sets of open seat primary elections whose turnout should be affected by a contested presidential primary. During the period 1980-2004, we find no statistically significant evidence that MCs whose open seat primary occurs on the same day as a contested presidential primary have relatively moderate roll call voting positions. 
Table 2. Primary elections and roll call voting positions 1948-2006.

\begin{tabular}{lccccc}
\hline & \multicolumn{2}{c}{ Newly elected } & & \multicolumn{2}{c}{ All senators } \\
\cline { 2 - 3 } \cline { 5 - 6 } & $(1)$ & $(2)$ & & $(3)$ & $(4)$ \\
\hline Primary turnout & -0.097 & 0.411 & -0.399 & 0.342 \\
& $(0.183)$ & $(0.338)$ & & $(0.212)$ & $(0.178)$ \\
Observations & \multicolumn{2}{c}{292} & & 2,484 \\
Contested primaries & -0.018 & 0.054 & -0.017 & 0.056 \\
& $(0.053)$ & $(0.096)$ & $(0.041)$ & $(0.030)$ \\
Observations & \multicolumn{3}{c}{250} & & 2,078 \\
Close primaries & -0.051 & -0.039 & -0.036 & 0.049 \\
Observations & $(0.063)$ & $(0.123)$ & $(0.048)$ & $(0.033)$ \\
\hline
\end{tabular}

Standard errors clustered by state-party are in parentheses. The specifications in columns 2 and 4 include state-party fixed effects which differ before and after 1974 . Columns 3 and 4 include Congress-party fixed effects.

as above but now include all senators - incumbent and newly elected — and measure turnout as the average turnout in the six years prior to and including the election at time $t, \bar{T}_{j k t}{ }^{17}$ We also now include Congress-party fixed effects. The estimate of $\theta$ in column 3 (row 1 ) is again not statistically significant but the coefficient is relatively large. A two-standard-deviation increase in turnout is associated with a shift in the individual contribution to polarization of less than a third of a standard deviation. While the standard errors are large, even if we use the largest estimate of $\theta$ within the $95 \%$ confidence interval, a two-standard-deviation increase in turnout is associated with a decrease in the individual contribution to polarization of less than 0.68 of a standard deviation. Moreover, this result mainly reflects the high turnout and moderate DW-NOMINATE scores of Democratic senators in the South. When southern states prior to 1990 are excluded from the analysis, the coefficient drops to $20 \%$ of the magnitude of the estimate which includes southern states in the 1970s and 1980s. Also, the estimate of $\theta$ in column 4 (row 1), which includes state-party fixed effects, is no longer statistically significant and the point estimate is positive, the opposite of what would we would expect given the popular claims. Thus, the evidence that low turnout is related to senators with more extreme roll call voting positions is weak at best.

\section{Ideologically Polarized Primary Electorates, 1992-2004}

To further examine the relationship between the ideological position of primary voters and senators' roll call voting positions, we use the state level average ideological position of presidential primary exit poll respondents described above. Assuming that

17 The substantive findings are robust to the number of years used to calculate turnout. 
Table 3. Ideological composition of electorate and roll call voting positions, 1992-2004.

\begin{tabular}{lccc}
\hline & Democrats & Republicans & Ideological gap \\
\hline Primary electorate & -0.119 & 0.480 & -0.185 \\
& $(0.242)$ & $(0.272)$ & $(0.224)$ \\
General electorate & 0.943 & 1.232 & -0.005 \\
\multirow{2}{*}{ Observations } & $(0.319)$ & $(0.399)$ & $(0.400)$ \\
& 31 & 31 & 25 \\
\hline
\end{tabular}

the presidential and non-presidential primary electorates have similar ideological leanings, we would expect states with more polarized primary electorates to also have more polarized Senate delegations.

To estimate this relationship between senators' individual contributions to polarization and preferences of the primary electorate we use the following specification:

$$
\bar{I}_{j k}=\alpha_{k}+\theta_{1} \bar{P}_{j k}+\theta_{2} \bar{G}_{j k}+\epsilon_{j k},
$$

where $\bar{I}_{j k}$ is the average individual contribution to polarization of incumbents in state $j$ from party $k$ between 1992 and 2004; and $\bar{P}_{j k}$ and $\bar{G}_{j k}$ are the average ideological positions of primary and general election exit poll respondents who either voted in the primary for party $k$ or voted in the general election and identify with party $k$.

The estimates of $\theta_{1}$ and $\theta_{2}$, shown in columns 1 and 2 of Table 3 , suggest that the ideological position of the general electorate exit poll respondents has a stronger association with senators' contributions to polarization than the ideological position of the primary electorate. This is true for senators of both parties.

We can also examine whether the gap in Democratic and Republican senators' DWNOMINATE scores is related to the ideological gap in the primary electorates using a similar specification as in Equation (3), but redefining the variables to reflect the differences between the parties' senators and electorates. The coefficient estimates in column 3 reveal no statistically significant relationship between the partisan ideological gap among the primary exit poll respondents and the partisan gap among senators' DWNOMINATE scores - i.e. a large ideological gap between Democratic and Republican primary voters in a state is not associated with a large gap in Democratic and Republican senators' DW-NOMINATE scores within that same state.

\section{PRIMARY COMPETITION AND SENATE POLARIZATION}

Another popular belief is that the electoral threat of facing a challenger with a more extreme ideological or partisan position in the primaries is one of the factors contributing to polarization in Congress. Differences in the threat of primary competition across states may arise due to state-specific characteristics, such as ballot access regulations, 
campaign finance laws, and other election laws. The differences may also arise from the structure of the political party organizations. Political parties with internal factional divisions are likely to have more primary competition. In addition, idiosyncratic factors may affect particular candidates at particular times - e.g., scandals, career trajectories of co-partisans who are potential challengers, and personal rivalries with party or interest group leaders.

Using a very simple model we first discuss why the competition MCs face in their own primary elections is a poor measure of the threat of primary competition affecting MCs' roll call voting positions. We demonstrate that this measure will lead to a biased estimate of the relationship between the threat of primary competition and polarization in Congress. We then demonstrate how the threat of primary competition may be better measured using the average level of primary competition across several down-ballot statewide offices. We construct such a measure using a new data set of primary election outcomes for down-ballot statewide offices. ${ }^{18}$

The second part of this section examines whether this measure is correlated with senators' roll call voting positions. As above we first examine whether the competitiveness of primaries in the year senators are initially elected is correlated with their roll call voting position during their first Congress session. We then examine whether the competitiveness of primary elections has an effect on all senators. We find little evidence that the competitiveness of the primary environment is significantly related to senators' roll call positions.

\section{Measuring the Threat from Primary Competition}

As noted in the Introduction, many scholars have argued that members of Congress respond to electoral threats. Several scholars, for example, argue that when gerrymandering produces "safe" districts — districts where one party is clearly favored in the general election - then congressional incumbents adopt more extreme positions in an attempt to reduce the threat posed by potential primary challengers.

Ideally, we would like to estimate the impact of primary election threats on the ideological positions taken by members of Congress. Unfortunately, we cannot directly measure primary electoral threats. As noted above, previous studies have used realized primary competition as a proxy for these threats. However, if the deterrence logic above holds, then the realized level of competition will depend upon incumbents' ideological position. Therefore a regression of incumbents' positions on realized primary competition will not yield a consistent estimate of the relationship of interest.

A simple model may clarify this claim. First, assume that the realized level of primary competition faced by incumbent $i$ is positively related to a latent threat level, $T_{j}$, and negatively related to the incumbent's roll call score:

$$
C_{i j}=\beta_{2} T_{j}-\gamma N_{i j}+\mu_{i j}
$$

18 See Ansolabehere et al. (2006b) for a description of this data set. 
The variable $T_{j}$ captures features of the electoral environment mentioned above, and $\mu_{i j}$ captures idiosyncratic factors peculiar to $i$ 's situation. The middle term captures the "scare-off" effect - controlling for the latent threat level, incumbents who are more extreme are less likely to face a serious primary challenge (as above, a higher $N_{i}$ is a more extreme score).

Assuming that incumbents take action to avoid primary challenges, the roll call score of incumbent $i, N_{i}$, will depend positively on the latent primary election threat level, $T_{j}$ (and possibly $\mu_{i j}$ assuming that the incumbent observes $\mu_{i j}$ sufficiently in advance):

$$
N_{i j}=\beta_{1} T_{j}+\epsilon_{i j}
$$

Substituting Equation (5) into Equation (4) yields:

$$
N_{i j}=\frac{\beta_{1}}{\beta_{2}-\beta_{1} \gamma} C_{i j}+\left[\epsilon_{i j}-\frac{\beta_{1}}{\beta_{2}} \mu_{i j}\right]\left[\frac{\beta_{2}}{\beta_{2}-\beta_{1} \gamma}\right] .
$$

Given that $T_{j}$ and $\mu_{i j}$ are unobservable, the only quantity of interest we can estimate is $\beta_{1} / \beta_{2}$. If $\gamma \neq 0$ then regressing $N_{i j}$ on $C_{i j}$ will lead to an upwardly biased estimate of $\beta_{1} / \beta_{2}$ (this is an example of classic simultaneous equation bias). Furthermore, even if $\gamma=0$ the estimated regression coefficient will still be biased, since $C_{i j}$ and $\mu_{i j}$ are correlated as written in Equation (4) (this is an example of classic measurement error bias).

Rather than using $C_{i j}$ as the regressor, we propose using the average level of realized primary competition for down-ballot statewide races, $\bar{C}_{j} .{ }^{19}$ While not a panacea, there are conditions under which this approach has clear advantages over using $C_{i j}$. One condition is that $\gamma=0$, so there is no simultaneity and the only problem with using $C_{i j}$ is measurement error. In this case if the $\mu_{i j}$ s are not too highly correlated, then $\bar{C}_{j}$ will be a more accurate measure of $\beta_{2} T_{j}$. Another condition is that ideology is not as salient in down-ballot races as it is in senate primary races. In the extreme case $\gamma=0$ for down-ballot races - i.e. the ideological position of candidates for down-ballot offices does not affect the realized level of competition - our estimate will not be biased. We suspect that $\gamma>0$ for down-ballot candidates, but it is probably smaller than for Senate candidates. This may be because ideological positions are less relevant for these offices e.g., secretary of state, auditor, and treasurer are mainly bureaucratic posts - or because voters have much less information about the ideological positions of the candidates for these offices.

\section{Threat of Primary Competition and Roll Call Voting Behavior}

According to the above discussion, averaging primary competition across several downballot offices is likely to be a better measure of the threat of facing a primary challenger than senators' own primary competition. We use two different measures of primary

19 Down-ballot statewide offices are statewide offices below senator and governor. 
competition: (i) the proportion of primary elections that are contested; and (ii) the proportion of primary elections where the nominee is selected with less than $60 \%$ of the vote. We use the average level of primary competition from six years prior to and including the Congress of interest. ${ }^{20}$

We estimate the relationship between individual senators' contributions to polarization and primary competition using the following specification:

$$
I_{i j k t}=\alpha_{j k}+\theta C_{j k t}+\gamma_{k t}+\epsilon_{i j k t},
$$

where $I_{i j k t}$ is the individual contribution to polarization of senator $i$ in state $j$ and party $k$ in the first two years following their first election at time $t$; $C_{j k t}$ is the measure of primary competition in state $j$ 's party $k$ at time $t$; and $\alpha_{j k}$ and $\gamma_{k t}$ are state-party and Congressparty fixed effects, respectively. As above we allow the state-party fixed effect to vary between the pre- and post-1974 periods.

The estimates of $\theta$ in Table 2 provide little evidence that the competitiveness of primaries when senators are first elected is related to their contribution to polarization during their first elected term in office. The results are not statistically significant. When state-party fixed effects are not included or when competition is measured by the proportion of close races, the estimate of $\theta$ is negative - i.e., more primary competition is associated with more moderate roll call voting scores. The magnitude of the point estimate is also not very large. In the analysis including state-party fixed effects, a twostandard-deviation change in the proportion of contested primary elections in a newly elected senator's state is associated with less than 0.16 of a standard deviation shift in the senator's contribution to polarization. Note, however, that the standard errors on the estimate of $\theta$ are fairly large. If we use the maximum estimate of $\theta$ within the $95 \%$ confidence interval, we find that a two-standard-deviation increase in primary contestation is associated with about a 0.71 standard deviation higher individual contribution to polarization.

Another possibility is that senators adjust their policy positions in response to the changes in the competitiveness of primaries over time. Although primary competition overall has not been increasing during the period when congressional roll call voting has become more polarized, the variation in primary competition may explain some of the variation across states over time. We use the same specification as in Equation (7) above, but now we include all senators. The estimates of $\theta$ in columns 3 and 4 of Table 2 are all small and insignificant. Thus, there is little evidence that senators' contributions to polarization and our measures of primary competition have a strong positive correlation. The point estimate of $\theta$ is even negative when state-party fixed effects are not included. When state-party fixed effects are included a two-standard-deviation increase in the proportion of contested primaries in a state is associated with a change of less than 0.16 of a standard deviation in individual senators' contributions to polarization. Using

20 We checked the sensitivity of our estimates to the length of the window, and also to the choice of which races are used - all races, incumbents-contested races only, and open seat races - in constructing the primary competition measures. The substantive interpretation of the findings reported is not significantly affected by the different measures. 
the maximum estimate of $\theta$ within $95 \%$ confidence interval, a two-standard-deviation increase in primary competition is associated with a third of a standard deviation higher individual contribution to polarization.

\section{ROLL CALL VOTING POSITIONS AND ELECTORAL OUTCOMES}

Despite the popular perception that competition in primary elections provides an electoral incentive for representatives to take more extreme policy positions, the results in the above sections provide little evidence that primary elections are associated with polarization in roll call voting. One of the assumptions underlying the conventional wisdom is that MCs have an electoral incentive to take extreme roll call voting positions. Although there are some empirical findings that House members with relatively extreme roll call voting scores do better in primary elections (Brady et al., 2007), there are also findings that there are electoral benefits in the general elections from taking more moderate roll call voting positions (Ansolabehere et al., 2001; Canes-Wrone et al., 2002). Even though primary elections may provide some electoral incentive for MCs to take extreme positions, whether or not candidates respond to these incentives also depends upon how their position will affect general election outcomes.

We begin this section by re-examining the claim that extreme roll call voting positions are positively correlated with primary election outcomes. We then compare these results with the relationship between roll call voting positions and general election outcomes to examine the overall electoral costs candidates potentially face from not taking extreme policy positions. Finally, we examine the political careers of moderate senators to determine whether they tended to leave Congress after a primary election defeat.

Note that in this section, we follow the literature and use DW-NOMINATE scores, which is not deviated from their party means as in the above sections, as our main independent variable of interest. We orient the scores so that for each party a higher DW-NOMINATE score indicates a more extreme roll call voting position.

\section{Roll Voting and Primary Election Outcomes}

Our analysis of primary election outcomes and roll call voting behavior focuses on the Senate. The multi-member district feature of U.S. Senate elections means that the same constituency may be represented by two senators from the same party but different roll call voting positions. We exploit this feature to examine whether the variation in the primary election vote shares of senators from the same party and state is related to their roll call voting positions. Conventional wisdom is that senators with relatively partisan roll call voting positions will have relatively high vote shares in the primary elections. We also take advantage of the lack of redistricting in the Senate that gives greater flexibility in making comparisons of senators' roll call voting records over time.

Since many primary elections are uncontested, we first examine whether senators' roll call voting positions are related to whether they face primary challengers. For this analysis we use a simple linear probability model. The two dependent variables of interest 
are: (1) whether the senator faces a challenge in his or her primary; and (2) whether the senator faces a close primary challenge (i.e., the nominee wins with less than $60 \%$ of the primary vote). The main independent variable of interest is the candidate's roll call voting position, which we measure using DW-NOMINATE scores. We also include the degree of primary contestation for all down-ballot statewide offices in the previous six years as well as state party fixed effects and an indicator variable for whether there is an incumbent in the primary race. ${ }^{21}$

The results presented in the top section of Table 4 provide some evidence that senators' DW-NOMINATE scores are correlated with whether they are challenged in primary elections in the expected direction - i.e., candidates with more extreme position are less likely to face a primary challenge. This effect is statistically significant when stateparty fixed effects are not included. A two-standard-deviation change in a senator's DW-NOMINATE score is associated with an $11 \%$ reduction in the probability of facing

Table 4. Linear probability model of primary contestation and roll call voting positions in the Senate, 1948-2006.

\begin{tabular}{|c|c|c|c|c|}
\hline & (1) & (2) & (3) & (4) \\
\hline \multicolumn{5}{|c|}{ Contested Senate Primary } \\
\hline Primary contestation & $\begin{array}{c}0.634 \\
(0.061)\end{array}$ & $\begin{array}{c}0.629 \\
(0.073)\end{array}$ & $\begin{array}{c}0.225 \\
(0.095)\end{array}$ & $\begin{array}{c}0.143 \\
(0.111)\end{array}$ \\
\hline DW-NOMINATE & & $\begin{array}{r}-0.298 \\
(0.110)\end{array}$ & & $\begin{array}{r}-0.141 \\
(0.191)\end{array}$ \\
\hline Incumbent & $\begin{array}{c}-0.281 \\
(0.031)\end{array}$ & $\begin{array}{r}-0.308 \\
(0.035)\end{array}$ & $\begin{array}{r}-0.283 \\
(0.032)\end{array}$ & $\begin{array}{c}-0.284 \\
(0.042)\end{array}$ \\
\hline Observations & 1,396 & 789 & 1,398 & 789 \\
\hline \multicolumn{5}{|c|}{ Closely Contested Senate Primary } \\
\hline Close primary & $\begin{array}{c}0.345 \\
(0.076)\end{array}$ & $\begin{array}{c}0.215 \\
(0.062)\end{array}$ & $\begin{array}{c}0.168 \\
(0.099)\end{array}$ & $\begin{array}{c}0.089 \\
(0.103)\end{array}$ \\
\hline DW-NOMINATE & & $\begin{array}{c}-0.061 \\
(0.065)\end{array}$ & & $\begin{array}{c}0.061 \\
(0.131)\end{array}$ \\
\hline Incumbent & $\begin{array}{c}-0.336 \\
(0.024)\end{array}$ & $\begin{array}{c}-0.292 \\
(0.033)\end{array}$ & $\begin{array}{r}-0.336 \\
(0.025)\end{array}$ & $\begin{array}{r}-0.281 \\
(0.037)\end{array}$ \\
\hline Observations & 1,392 & 787 & 1,392 & 787 \\
\hline
\end{tabular}

Columns (3) and (4) include state-party fixed effects which are allowed to differ after 1974. Standard errors clustered by state-party are in parentheses.

21 For incumbents we use the DW-NOMINATE score for the Congress just prior to the election. In order to include cases for non-incumbents we use the DW-NOMINATE scores for the Congress just after the election. 
a primary contestant. The coefficient is no longer statistically significant when stateparty fixed effects are included. The results in the bottom section of Table 4 suggest that whether the senator faced a close primary challenge is not strongly related to their DW-NOMINATE score.

The second relationship of interest is whether the roll call voting position of senators who are challenged in a primary is related to the number of votes they receive in the primary election. Again the conventional wisdom is that senators with relatively more extreme policy positions should have relatively higher vote shares in the primary. We measure senators' vote shares as the proportion of votes cast for the top two candidates. The main independent variable is the senator's roll call voting position. We include state-party fixed effects, which we allow to vary before and after 1974, to account for differences in primary electorates across states. We exploit the variation in roll call voting positions of members representing the same state.

The coefficient of interest, presented in column 1 of Table 5, is very close to zero and not statistically significant. ${ }^{22}$ Thus, when senators face a primary challenger, their roll call voting positions do not appear to be strongly related to their primary election vote shares.

\section{Roll Voting and General Election Outcomes}

As the above discussion suggests, primary elections appear to provide little electoral motivation for senators to take extreme roll call voting positions. We now turn to the

Table 5. Election outcomes and roll call voting in the Senate, 1948-2006.

\begin{tabular}{lccc}
\hline & Primary election & \multicolumn{2}{c}{ General election } \\
\hline DW-NOMINATE score & 0.002 & -0.135 & -0.127 \\
& $(0.078)$ & $(0.021)$ & $(0.021)$ \\
Incumbent & 0.134 & 0.040 & 0.046 \\
& $(0.017)$ & $(0.005)$ & $(0.006)$ \\
Normal vote & & & 0.752 \\
& & & $(0.065)$ \\
Net incumbency & & & -0.034 \\
& & & $(0.007)$ \\
Observations & 548 & 1,022 & 925 \\
\hline
\end{tabular}

State-party fixed effects are included in all specifications. The specification in columns 2 and 3 also include Congress-party fixed effects. Standard errors clustered by state-party are in parentheses.

22 This coefficient is positive but still not statistically significant when we limit the sample to incumbents only. 
question of whether extreme roll call positions affect senators' success in general elections.

In the analysis above we used a simple fixed effects regression and assumed that state preferences were being captured by the state-party fixed effects. We use a similar specification to test the relationship between senators' roll call voting positions and their support in general elections. The dependent variable is the senator's vote share of the two party vote. The main independent variable of interest is the senator's roll call voting position, as measured by their DW-NOMINATE score. We include state-party and Congress-party fixed effects. In a second specification we include measures of the state normal vote using the average vote share of down-ballot offices for previous elections.

Table 6. Reasons why Senate moderates and "misfits" left the senate.

\begin{tabular}{|c|c|c|c|c|c|}
\hline \multicolumn{3}{|c|}{ Democrats } & \multicolumn{3}{|c|}{ Republicans } \\
\hline State & Senator & Reason & State & Senator & Reason \\
\hline $\mathrm{AL}$ & Sparkman & Retired & CT & Weicker & Lost general \\
\hline AL & Allen & Died in office & IL & Percy & Lost general \\
\hline AL & Shelby & Switched parties & $\mathrm{KS}$ & Pearson & Retired \\
\hline $\mathrm{AL}$ & Heflin & Retired & KY & Cooper & Retired \\
\hline $\mathrm{AR}$ & McClellan & Died in office & MA & Brooke & Lost general \\
\hline FL & Holland & Retired & MD & Mathias & Retired \\
\hline GA & Russell & Died in office & ME & W. Cohen & Retired \\
\hline GA & H. Talmadge & Lost general & ME & Snowe & Still serving \\
\hline GA & Nunn & Retired & ME & Collins & Still serving \\
\hline GA & Z. Miller & Retired & $\mathrm{MN}$ & Durenberger & Retired \\
\hline LA & Ellender & Lost primary & $\mathrm{NJ}$ & Case & Lost primary \\
\hline LA & R. Long & Retired & $\mathrm{NY}$ & Goodell & Lost general \\
\hline LA & Breaux & Retired & NY & Javits & Lost primary \\
\hline MS & Eastland & Retired & OR & Hatfield & Retired \\
\hline MS & Stennis & Retired & OR & Packwood & Retired \\
\hline $\mathrm{NC}$ & Ervin & Retired & $\mathrm{PA}$ & Schweiker & Retired \\
\hline $\mathrm{NC}$ & Jordan & Lost primary & $\mathrm{PA}$ & Heinz & Died in office \\
\hline $\mathrm{NE}$ & Zorinsky & Died in office & $\mathrm{PA}$ & Specter & Still serving \\
\hline $\mathrm{NE}$ & Nelson & Still serving & RI & J. Chafee & Died \\
\hline OK & Boren & Retired & RI & L. Chafee & Lost general \\
\hline $\mathrm{TX}$ & Krueger & Lost general & VT & Aiken & Retired \\
\hline VA & Byrd Jr. & Switched parties & VT & Stafford & Retired \\
\hline FL & Stone & Lost primary & VT & Jeffords & Switched parties \\
\hline $\mathrm{NC}$ & Morgan & Lost general & ME & Smith & Lost general \\
\hline TX & Bentsen & Resigned & ND & Andrews & Lost general \\
\hline
\end{tabular}


The results in Table 5 provide some evidence that incumbent senators with extreme roll call voting positions have lower vote shares in the general election than moderates. The increasing competitiveness of general election competition suggests that incumbent senators who wish to retain their position have a strong incentive to take moderate positions. The evidence is not as robust for open seat races.

\section{What Happens to Moderates in Congress?}

Finally, if taking moderate policy positions leaves candidates vulnerable in primary elections, then we would expect a disproportionately large number of moderate MCs to leave office because they lose a primary election. We define moderate senators as Democrats with DW-NOMINATE scores of greater than -0.15 and Republicans with DW-NOMINATE scores of less than 0.10.

Table 6 lists the causes for why moderate senators left office. We focus on senators who served for more than one term between the 91st to the 110th Congress. Among the 25 moderate Democrats in the Senate during this period only 3 left office due to being defeated in a primary. Of the 25 moderate Republican only 2 left office due to being defeated in a primary. Overall, twice as many moderate senators lost in a general election as lost in a primary. Most simply retired. Of course, some of the retirements may have been strategic, with an electoral defeat likely. Also moderate senators who succeed in winning office may be different than other senators. Nonetheless, Table 6 at least suggests that primary competition does not have an obvious role in forcing moderate incumbent senators out of office.

\section{CONCLUSIONS}

Scholars, journalists, and politicians have long claimed that primary elections contribute to the ideological polarization in political parties. The logic behind this claim is very straightforward: In order to gain a major party nomination, politicians need to take positions that appeal to the more ideologically extreme primary electorates. This argument has come under increased scrutiny with the recent rise of polarization between the political parties and the search for an explanation (e.g., Fiorina et al., 2006; McCarty et al. 2006). The empirical evidence linking primaries and congressional polarization has been mixed.

In this paper we begin by examining three variables that should be correlated with extreme policy positions by members of Congress if the conventional wisdom is correct about primaries and polarization. The three variables are: (1) the introduction of primaries; (2) the polarization of the primary electorates; and (3) the threat of primary competition. Our analysis of these three variables points to the conclusion that primary elections have little or no association with polarization in congressional roll call voting behavior.

This finding casts doubt on the conventional wisdom that the primary system in the United States fuels the growing ideological schism between the parties. That conjecture 
Table A1. Primary electorate ideology and turnout 1992-2004.

\begin{tabular}{lccccc}
\hline & \multicolumn{2}{c}{ Democrats } & & \multicolumn{2}{c}{ Republicans } \\
\cline { 2 - 3 } \cline { 5 - 6 } & $(1)$ & $(2)$ & & $(3)$ & $(4)$ \\
\hline Primary turnout & -0.011 & -0.014 & & -0.009 & -0.007 \\
Ideology of general electorate & $(0.004)$ & $(0.006)$ & & $(0.003)$ & $(0.004)$ \\
& 1.118 & 0.059 & & 0.760 & -0.203 \\
Observations & $(0.122)$ & $(0.269)$ & & $(0.180)$ & $(0.160)$ \\
\hline
\end{tabular}

Each election is a separate observation in columns (2) and (4). Columns (2) and (4) include state and year fixed effects. Standard errors clustered by state are in parentheses.

is widely taken as a truism in public discourse and among political scientists, from those writing for popular audiences to those writing textbooks to those working on mathematical models of political strategy. It is even reaching into the comparative politics literature, especially in Latin America, where several countries use primary elections (see Carey and Polga-Hecimovich, 2006). This paper contributes to the growing doubt about this claim (see also Abramowitz, 2008).

The positive finding that does emerge from this research underscores a central conjecture of political science, namely, general election competition creates pressure for ideological convergence and moderation. That effect emerges clearly from U.S. Senate elections. Even still, general election pressures are not sufficient to produce complete convergence of the parties. Finding the chief causes of party differentiation and moderation, then, remains an important problem. The evidence here indicates that the primary election system does not appear to be among the important factors producing polarization of the political parties in the United States.

\section{REFERENCES}

Abramowitz, A. 2008. "Don't Blame Primary Voters for Polarization.” The Forum 5: Article 4.

Ansolabehere, S., S. Hirano, and J. M. Snyder, Jr. 2006a. "What Did the Direct Primary do to Party Loyalty in Congress?" In Process, Party and Policy Making: Further Nem Perspectives on the History of Congress eds. D. Brady and M. D. McCubbins, Stanford University Press.

Ansolabehere, S., J. M. Hansen, S. Hirano, and J. M. Snyder, Jr. 2006b. "The Decline of Competition in U.S. Primary Elections, 1908-2004.” In The Marketplace of Democracy eds. M. McDonald and J. Samples, Brookings Institution Press: pp. 74-101.

Ansolabehere, S., J. M. Hansen, S. Hirano, and J. M. Snyder, Jr. 2007. "The Incumbency Advantage in U.S. Primary Elections." Electoral Studies 26: 660-668.

Ansolabehere, S., J. M. Snyder, Jr., and C. Stewart III. 2001. "Candidate Positioning in U.S. House Elections." American Fournal of Political Science 45: 136-159.

Aranson, P. H. and P. C. Ordeshook. 1972. "Spatial Strategies for Sequential Elections." In Probability Models of Collective Decision Making, eds. R. G. Niemi and H. F. Weisberg. Columbus: Charles E. Merrill: pp. 298-331. 
Bullock, W. and J. D. Clinton. 2010. "More a Molehill than a Mountain: The Effects of Open Primaries on Legislator Behavior Using the Case of California." Typescript.

Burden, B. C. 2001. "The Polarizing Effects of Congressional Primaries." In Congressional Primaries in the Politics of Representation, eds. P. F. Galderisi, M. Lyons, and M. Ezra. Lanham, MD: Rowman and Littlefield.

Burden, B. 2004. "Candidate Positioning in US Congressional Elections." British Fournal of Political Science 34: 211-227.

Brady, D., H. Han, and J. C. Pope. 2007. "Primary Elections and Candidate Ideology: Out of Step with the Primary Electorate?" Legislative Studies Quarterly 32: 79-105.

Canes-Wrone, B., D. W. Brady, and J. F. Cogan. 2002. "Out of Step, Out of Office: Electoral Accountability and House Members' Voting." American Political Science Reviem 96: 127-140.

Carey, J. and J. Polga-Hecimovich. 2006. "Primary Elections and Candidate Strength in Latin America." Fournal of Politics 68: 530-543.

Coleman J. S. 1972. "The positions of political parties in elections." In Probability Models of Collective Decision Making, eds. R. G. Niemi, W. F. Columbus, OH: Charles E. Merrill: pp. 332-357.

Crotty, W. J. and J. S. Jackson, III. 1985. Presidential Primaries and Nominations. Washington: Congressional Quarterly Press.

Fiorina, M. 1974. Representatives, Roll Calls, and Constituencies. Lexington, MA: D.C. Heath.

Fiorina, M. P., S. J. Abrams, and J. C. Pope. 2006. Culture war? The Myth of a Polarized America. New York: Pearson Longman

Fiorina, M. P. and M. S. Levendusky. 2006. "Disconnected: The Political Class versus the People." In Red and Blue Nation? Characteristics and Causes of American Polarized Politics. eds. P. S. Nivola and D. Brady. Washington, D.C.: Brookings Institution Press: pp. 49-71.

Galston, W. A. and P. S. Nivola. 2006. "Delineating the Problem." In Red and Blue Nation? Characteristics and Causes of American Polarized Politics. eds. P. S. Nivola and D. Brady. Washington, D.C.: Brookings Institution Press.

Gerber, E. R. and R. B. Morton. 1998. "Primary Election Systems and Representation.” Fournal of Law, Economics, and Organization 14: 304-324.

Grofman, B. and T. L. Brunell. 2001. "Explaining the Ideological Differences Between the Two U.S. Senators Elected from the Same State: An Institutional Effects Model.” In Congressional Primaries and the Politics of Representation, eds. P. F. Galderisi, M. Ezra, and M. Lyons. Lanham, MD: Rowman and Littlefield Press.

Hacker, J. S. and P. Pierson. 2006. Off Center: The Republican Revolution and the Erosion of American Democracy. New Haven, CT: Yale University Press.

Huntington, S. P. 1950. "A Revised Theory of American Party Politics." The American Political Science Reviem. 44: 669-677.

Jacobson, G. 2004. The Politics of Congressional Elections, 6th ed. New York: Pearson.

Key, V. O., Jr. 1956. American State Politics: An Introduction. New York: Alfred A. Knopf.

King, D. 2003. "Congress, Polarization, and Fidelity to the Median Voter." Unpublished Manuscript.

Lengle, J. I. 1981. Representation and Presidential Primaries. Westport, CT: Greenwood.

Mann, T. 2005. "Redistricting Reform.” The National Voter June 2005.

McCarty, N., K. T. Poole, and H. Rosenthal. 2006. Polarized America: The Dance of Ideology and Unequal Riches. Cambridge, MA: MIT Press.

McCarty, N., K. T. Poole and H. Rosenthal. 2009. "Does Gerrymandering Cause Polarization?” American Fournal of Political Science 53: 666-680.

Norrander, B. 1989. "Ideological Representativeness of Presidential Primary Voters." American Fournal of Political Science 33: 570-587.

Ornstein, N. 2006. "Vote - or Else." New York Times. August 10, 2006: Op-ed page.

Owen, G. and B. Grofman. 2006. "Two-Stage Electoral Competition in Two-Party Contests: Persistent Divergence of Party Positions." Social Choice and Welfare 26: 547-569.

Polarized Nation? The Washington Post November 14, 2004: Op-ed page.

Poole, K. T. 1997. "Changing Minds? Not in Congress." Unpublished Manuscript.

Pearson, K. and J. L. Lawless. 2007. "Primary Competition and Partisan Polarization in the U.S. House of Representatives, 1992-2006.” Unpublished Manuscript. 
Ranney, A. and L. D. Epstein. 1966. "The Two Electorates: Voters and Non-Voters in a Wisconsin Primary." The Fournal of Politics 28: 598-616.

Ranney, A. 1968. "Representativeness of Primary Electorates." Midmest Fournal of Political Science 12: 224-238.

Sinclair, B. 2006. Party Wars: Polarization and the Politics of National Policy Making. Norman, OK: University of Oklahoma.

Stone, W. 1980. "The Dynamics of Constituency: Electoral Control of the House." American Politics Ouarterly 8: 399-424.

Theriault, Sean M. 2006. "Party Polarization in the U.S. Congress." Party Politics 12: 483-503.

Vasyl, M. Jr. "Voters need a new political party." Chicago Tribune, May 2, 1992. p. 20.

Wright, G. C. Jr. and M. B. Berkman. 1986. "Candidates and Policy in United States Senate Elections." The American Political Science Reviem. 80: 567-588. 